\title{
Detection of cancer clones in human gastric adenoma by increased DNA-instability and other biomarkers
}

\author{
A. Sun, S. Noriki, Y. Imamura, M. Fukuda \\ Department of Pathology, Fukui Medical University, Matsuoka, Fukui, Japan
}

(C)2003, European Journal of Histochemistry

An immunohistochemical differential staining of cancerous cells with anti-cytidine antibody after denaturation of nuclear DNA by acid hydrolysis with $2 \mathrm{~N} \mathrm{HCl}$ at $30^{\circ} \mathrm{C}$ for $20 \mathrm{~min}$ (DNA-instability test) has been used as a marker of malignancy. The test was applied to bioptic tissues of human gastric polyp assessed histopathologically as foveolar hyperplastic polyp (13 cases), mild (58 cases), moderate (86 cases), and severe (20 cases) dysplasia, and adenocarcinomas (14 cases). The serial sections of the same tissues were also subjected to immunohistochemical staining for Ki67, p53, DNA-fragmentation factor (DFF45), and basic fibroblast growth factor (bFGF). The DNA-instability test was positive in $14(100 \%)$ adenocarinoma cases, 20 (100\%) severe dysplasia cases, 52 (60.5\%) moderate dysplasia cases, and 12 (20.7\%) mild dysplasia cases, indicating malignancy. All foveolar hyperplastic polyps were negative to the DNA-instability testing. Furthermore, the percentage of glands positive in the DNA-instability test steadily increased in going from mild $(10 \%)$, to moderate $(40 \%)$, to severe $(100 \%)$ dysplasia, and adenocarcinoma (100\%). All other biological markers tested in the present study showed significantly higher values in the adenoma glands, being positive to DNA-instability testing, irrespective of the dysplasia grade, as compared to those in the adenoma glands that were negative to DNA-instability testing. Furthermore, the former values were comparable to those in adenocarcinoma. These results indicate that cancer cell clones are already present at the adenoma stages showing a positive DNA-instability test, enhanced proliferative activity, p53 mutation, induction of DFF45 and bFGF. These factors allow cancer cell proliferation, producing heterogeneous subclones due to DNA-instability, enhancing their survival by escaping apoptosis, and providing abundant nutrients during the early-stage progression of gastric cancer. Based on these findings, we herein propose the concept of "procancer" (as opposed to "precancer") as being a unique stage during the course of carcinogenesis and cancer progression. We designate the term to cancer clones at the very early stages of malignant progression that do not show distinguishable morphological atypia but do show positive DNA-instability testing and positive staining for various biomarkers such as Ki67, p53, DFF45, and bFGF. We also define the abnormal positive staining of these biomarkers, including the DNA-instability test as "functional atypia", compared to the ordinary morphological atypia.

Key words: human gastric adenoma, DNA instability, Ki67, p53, DFF45, bFGF
Correspondence: Prof. Masaru Fukuda, MD, Department of Pathology, Fukui Medical University, Matsuoka, Yoshida-Gun, 910-1193, Fukui, Japan. Phone: international +81-776-618317. Fax: international +81-776-61-8103.

E-mail: west@fmsrsa.fukui-med.ac.jp

Paper accepted on December 4, 2002

European Journal of Histochemistry 2003; vol. 47 issue 2 [Apr-Jun]:111-122

G astric adenoma is defined by the World Health Organization (WHO) as circumscribed benign lesions, composed of tubular and/or villous structures showing intraepithelial neoplasia (Fenoglio-Preiser et al., 2000), and is widely considered to be a premalignant lesion (Correa et al., 1992). According to the degree of cellular and structural dysplasia, gastric adenoma is divided into two qualitative grades (low-grade and high-grade dysplasia) or three qualitative grades (mild, moderate and severe dysplasia) (Ming et al., 1984; Tosi et al., 1989; Goldstein and Lewin, 1997). Many authors have investigated the relationship between gastric adenoma and cancer, and showed that the frequency of malignant transformation from adenoma to carcinoma depends on size and histological grade of adenoma (Nakamura et al., 1988; Xuan et al., 1991; Tsujitani et al., 1992). Most investigators agree that severe, or high grade dysplasia is the most important precursor of gastric cancer and strongly recommend gastrectomy, endoscopic mucosal resection (EMR) or polypectomy, particularly in light of the high percentage of early gastric cancer (Lansdown et al., 1990; Farinati et al., 1991; Di Gregorio et al., 1993). However, there remains disagreement regarding of the risk of malignant potential for adenomas with mild and/or moderate dysplasia. Some authors believe that adenomas with mild and moderate dysplasia progress slowly, remain stable or regress (Saraga et al., 
1987; Farinati et al., 1989), while others have reported that the progression to severe dysplasia or evolution into gastric carcinoma ranged between $19 \sim 21 \%$ and $33 \sim 40 \%$ in mild and moderate dysplasia, respectively (Rugge et al., 1991; Fertitta et al., 1993; Rugge et al., 1994).

The morphological criteria for evaluating the potential malignancy, or the probability of transition to overt cancer of gastric adenoma, however, are quite ambiguous and controversial, and the validity of them is confusing in everyday diagnosis. In order to solve this problem, many histochemical and molecular biological methods have been applied in gastric adenoma and cancer in the search for reliable marker(s) of malignancy and potential malignancy. For example, brain type glycogen phosphorylase (Shimada et al., 1999), sulphomucins (Jass and Filipe, 1980), p53 (Matozaki et al., 1992; Shiao et al., 1994), c-erbB-2 (Sasano et al., 1993), bcl-2 (Ayhan et al., 1994), PCNA (Miracco et al., 1995; Ozercan et al., 2000), DNA topoisomerase (Yabuki et al., 1996), Ki67 (D'Errico et al., 1991; Hoshi et al., 1998), AgNOR (Ozercan et al., 2000), APC LOH and mutation (Nakatsuru et al., 1993; Sanzortega et al., 1996), genetic instability (Semba et al., 1996; Kim et al., 1999; Kim et al., 2000; Kashiwagi et al., 2000), DNA-ploidy analysis (Bearzi et al., 1992) and H. pylori infection (Wu et al., 1997; Wang et al., 2002) have been used for this purpose.

All the above diagnostic tools have demonstrated the presence of abnormal gene expression and protein synthesis, disturbed cytodifferentiation, stimulated cell proliferation activity and DNA abnormalities during the course of overt malignant progression in gastric adenoma. However, none of them could be used as a specific marker for malignancy diagnosis, although some of the abnormalities were statistically significant.

In this regard, Fukuda et al $(1986,1993)$ found that nuclear DNA of cancerous cells was always, and without exception, much more unstable than that of comparable benign tumor cells and normal cells, irrespective of epithelial or mesenchymal origin. They also developed the method of differential fluorescent or immunohistochemical staining of cancerous cells after denaturation of DNA by acid hydrolysis. Using this method (the DNA-instability test), cancerous clones could be identified during early stages of carcinogenesis in so-called borderline or precancerous lesions such as colorectal ade- noma (Nitta et al., 1993), otorhinolaryngeal borderline lesions (Tsuzuki et al., 1994), bone giant cell tumors (Azuchi et al., 1998), uterine cervical dysplasia (Khaled et al., 2000), oral leukoplakia (Iwasa et al., 2001), 20-methylcholanthreneinduced squamous cell carcinoma of mouse epidermis (Hirai et al.,2001). Otaki et al. (1994) also demonstrated that all adenoma lesions with severe dysplasia can be regarded as malignant in nature existing at an early stage of cancer progression, using the DNA-instability test compared with PCNA immunohistochemistry and AgNORs parameter analysis. However, no data were obtained for mild dysplasia and the number of moderate dysplasia examined was only limited in the study.

In the present study, we used this DNA-instability test as a malignancy marker to identify cancer clones in human gastric adenoma including 58, 86 and 20 cases of mild, moderate and severe dysplasias, respectively. Cancer clones were identified by increased DNA-instability in gastric adenoma and they exhibited significantly higher values of Ki67 index and enhanced immunoreactivity for p53, DNA fragmentation factor 45(DFF45) and bFGF, compared with DNA-instability test-negative lesions.

\section{Materials and Methods}

A total of 191 biopsy specimens from human stomach, including 13 foveolar hyperplastic polyps, 164 adenomas and 14 adenocarcinomas were examined. The gastric adenoma lesions were divided into mild (58 cases), moderate (86 cases) and severe dysplasia (20 cases), based on the degree of structural and celluar atypia of glands (Rubio and Kato, 1988).

DNA-instability test. Paraffin-embedded $4 \mu \mathrm{m}$ thick sections were prepared after fixation with $10 \%$ buffered formalin for 24 hours at room temperature. They were deparaffinized with xylene and replaced by ethanol.

\section{(a) preblocking}

After washing in water, the intrinsic peroxidase was blocked with $0.03 \% \mathrm{H}_{2} \mathrm{O}_{2}$ solution dissolved in absolute methanol at room temperature for $15 \mathrm{~min}$ and rinsed with PBS $(\mathrm{pH} \mathrm{7.4)}$. The sections were mounted with $2 \%$ skim-milk (Yukijirushi, Sapporo, Japan) dissolved in PBS ( $\mathrm{pH} \mathrm{7.4)}$ at $37^{\circ} \mathrm{C}$ for 20 min to block the background adsorption of antiserum. Then they were reacted with the blocking 
solution [Histofine, Nichirei, PO(R) Japan] at room temperature, for $5 \mathrm{~min}$.

\section{(b) $\mathrm{HCl}$-hydrolysis and immunohistochemical stain- ing of single-stranded DNA}

The sections were then washed in water, and treated with $2 \mathrm{~N} \mathrm{HCl}$ at $30^{\circ} \mathrm{C}$ for 20 min for acid hydrolysis followed by re-washing in water. They were reacted with polyclonal antibody to cytidine Biogenesis, UK, 1:1500 dilution in PBS ( $\mathrm{pH} \mathrm{7.4)} \mathrm{at}$ $4^{\circ} \mathrm{C}$ overnight and rinsed with PBS ( $\mathrm{pH} \mathrm{7.4).} \mathrm{The}$ sections were reacted with biotinylated goat antirabbit IgG [Histofine, Nichirei, $\mathrm{PO}(\mathrm{R})$, Japan] at

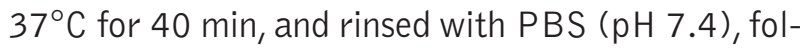
lowed by reaction with the avidin-biotin peroxidase complex [Histofine, Nichirei, PO(R), Japan] at $37^{\circ} \mathrm{C}$ for $30 \mathrm{~min}$, and further rinsed with PBS $(\mathrm{pH}$ 7.4).

\section{(c) Co-DAB reaction}

In order to visualize the peroxidase colour reaction, the sections were incubated with DAB (3,3'diaminobenzidine tetrahydrochloride) cobalt solution [DAB, Dojin, Kumamoto, Japan, 5 mg dissolved

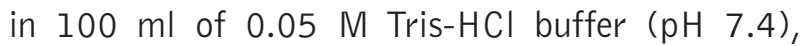
added with $2 \mathrm{ml}$ of $1 \% \mathrm{CoCl} 2$ and $10 \mu \mathrm{L}$ of $30 \%$ $\mathrm{H}_{2} \mathrm{O}_{2}$ solution at $20^{\circ} \mathrm{C}$ for $10 \mathrm{~min}$ and washed in water. Nuclear counterstaining was carried out with Kernechtrot (Kernechtrot, Chroma, Stuttgart, Germany, $0.1 \mathrm{~g}$ and aluminium sulphate $5 \mathrm{~g}$ dissolved in $100 \mathrm{~mL}$ distilled water).

\section{Immunohistochemical staining of Ki67, p53, bFGF and DNA- fragmentation factor (DFF45).}

Serial $4 \mu \mathrm{m}$-thick sections were prepared from the same specimens used for DNA-instability testing as described above. After washing with water, the intrinsic peroxidase activity was blocked as described above and washed with PBS ( $\mathrm{pH} 7.4$ ). The sections were irradiated in a poly-propylene slide holder with a cap filled with $10 \mathrm{mM}$ Na-citrate buffer ( $\mathrm{pH}$ 6.0), over a period of $5 \mathrm{~min}$, using an autoclave (Hirayama, $1.5 \mathrm{kw}$, Japan), and then reacted with the blocking solution [Histofine, Nichirei, PO (M), Japan)] at $20^{\circ} \mathrm{C}$ for 5 min. This was followed by reactions at $4^{\circ} \mathrm{C}$ overnight with following primary antibodies: anti-Ki67 antigen monoclonal antibody [Immuotech, MIB-1, 1:50 dilution in PBS (pH7.4)], anti-human p53 tumor suppressor protein monoclonal antibody [Dako, Clone D0$7,1: 100$ dilution in PBS ( $\mathrm{pH} \mathrm{7.4)],} \mathrm{and} \mathrm{anti} \mathrm{human}$
bFGF monoclonal antibody [Wako, clone78, 1:100 dilution in PBS $(\mathrm{pH}$ 7.4)]. Then sections were washed with PBS ( $\mathrm{pH} 7.4$ ), and further reacted with biotinylated rabbit anti-mouse IgG (Histofine, Nichirei, PO (M), Japan) at $37^{\circ} \mathrm{C}$ for $30 \mathrm{~min}$, followed by rinsing with PBS ( $\mathrm{pH} 7.4)$. They were allowed to react with the avidine-biotin-peroxidase complex at $37^{\circ} \mathrm{C}$ for $30 \mathrm{~min}$ (Histofine, Nichirei, PO ( M ), Japan) and rinsed with PBS ( $\mathrm{pH}$ 7.4). In order to visualize the peroxidase colour reaction, the sections were incubated with $0.02 \%$ DAB $[20 \mathrm{mg}$ DAB dissolved in $100 \mathrm{ml}$ of PBS ( $\mathrm{pH} \mathrm{7.4)]} \mathrm{at} \mathrm{room}$ temperature for $10 \mathrm{~min}$ and washed in water. Nuclear counterstaining was performed with hematoxylin.

Immunohistochemical staining for DNA-fragmentation factor was performed in a similar fashion except for using polyclonal anti-DNA-fragmentation factor antibody [NCL-DFFp, Novocastra, Newcastle, UK, 1:400 dilution in PBS ( $\mathrm{pH} \mathrm{7.4)]} \mathrm{as} \mathrm{the}$ primary antibody. Biotinylated goat anti-rabbit IgG was used this time as the secondary antiserum with the blocking solution for rabbit [Histofine, Nichirei, PO(R), Japan].

\section{Evaluations of immunohistochemical staining for DNA-instability, Ki67, p53, DFF45 and bFGF}

As for the DNA-instability test, the gland with more than several positively-stained cells was regarded as positive and the adenoma and adenocarcinoma with more than one positive gland was counted as positive lesion. The percent numbers of positive glands, mitosis and abnormal mitosis in the DNA-instability test-positive and -negative glands was also determined in all lesions. In serial sections of the same specimens, the percent number of cells positive for Ki67 (Ki67 index, KI) was determined by counting the positively-stained nuclei among more than 500 cells in each entire lesion, and was also determined in both DNA-instability test positive and negative glands, respectively. As for p53, DFF45 and bFGF, a case with more than 5\% positively stained cells, as determined in the same way used for counting KI, was regarded as positive.

\section{Statistical analysis}

The Ki67 index (KI) is presented as mean \pm S.D. Data were analysed using Student's t-test with a $p$ value $<0.05$ being considered significant. Staining for p53, DFF45, bFGF, and DNA-instability test are shown as positive percentage. Data were compared 
Table 1. The results of the DNA-instability test, and the immunohistochemical staining of Ki67, p53, DFF45, and bFGF. The statistical differences of KI values examined by Student's t-test using the value of foveolar hyperplastic polyp lesion as the standard. The statistical differences in DNA-instability test, p53, DFF45, and bFGF positive test were examined by the chi-square test using the values of mildly dysplastic adenoma as the standard. The values with meaningful differences $(p<0.05)$ are shown by asterisks.

\begin{tabular}{|c|c|c|c|c|c|}
\hline & $\begin{array}{c}\text { DNA- } \\
\text { instability } \\
\text { test } \\
(\%)\end{array}$ & $\begin{array}{c}K I \\
(\text { mean } \pm S . D .)\end{array}$ & $\begin{array}{l}p 53 \\
(\%)\end{array}$ & $\begin{array}{l}\text { DNA-frag- } \\
\text { mentation } \\
\text { factor } \\
\text { (\%) }\end{array}$ & $\begin{array}{l}\text { bFGF } \\
(\%)\end{array}$ \\
\hline Hyperplastic poly $(n=13)$ & $\begin{array}{c}0.0 E+01 \\
(n=0)\end{array}$ & $17.76 \pm 7.93$ & $\begin{array}{c}0.0 \mathrm{E}+01 \\
(\mathrm{n}=0)\end{array}$ & $\begin{array}{c}7.7 \\
(n=1)\end{array}$ & $\begin{array}{c}0.0 \mathrm{E}+01 \\
(\mathrm{n}=0)\end{array}$ \\
\hline Mild dysplasia ( $\mathrm{n}=58$ ) & $\begin{array}{c}20.7 \\
(n=12)\end{array}$ & $33.68 \pm 7.20 *$ & $\begin{array}{c}34.5 \\
(\mathrm{n}=20)\end{array}$ & $\begin{array}{c}58.6 \\
(n=34)\end{array}$ & $\begin{array}{c}32.8 \\
(n=19)\end{array}$ \\
\hline Moderate dysplasia $(n=86)$ & $\begin{array}{c}60.5 \\
(n=52)\end{array}$ & $48.64 \pm 8.58^{*}$ & $\begin{array}{c}65.1 \\
(n=56)\end{array}$ & $\begin{array}{c}69.8 \\
(n=60)\end{array}$ & $\begin{array}{c}47.7 \\
(n=41)\end{array}$ \\
\hline Severe dysplasia $(n=20)$ & $\begin{array}{c}100 \\
(n=20)\end{array}$ & $75.19 \pm 12.58 *$ & $\begin{array}{l}90.0 \\
(n=18)\end{array}$ & $\begin{array}{c}90 \\
(\mathrm{n}=18)\end{array}$ & $\begin{array}{c}75.0 \\
(n=15)\end{array}$ \\
\hline Dysplasia total $(\mathrm{n}=164)$ & $\begin{array}{c}51.2 \\
(n=84)\end{array}$ & $46.59 \pm 15.74 *$ & $\begin{array}{c}57.3 \\
(n=94)\end{array}$ & $\begin{array}{c}68.3 \\
(n=112)\end{array}$ & $\begin{array}{c}45.7 \\
(n=75)\end{array}$ \\
\hline Carcinoma ( $n=14$ ) & $\begin{array}{c}100 \\
(n=14)\end{array}$ & $77.13 \pm 14.98 *$ & $\begin{array}{c}85.7 \\
(n=12)\end{array}$ & $\begin{array}{c}100 \\
(n=14)\end{array}$ & $\begin{array}{l}57.1 \\
(n=8)\end{array}$ \\
\hline
\end{tabular}

in different cases and between DNA-instability test positive and negative adenomas by Chi-square test. A $p$ value $<0.05$ denoted the presence of a significant statistical difference.

\section{Results}

The results of the DNA-instability test, immunohistochemical staining of Ki67, p53, DFF45 and bFGF are summarized in Table 1. The data of Ki67, p53, DFF45 and bFGF in relation to the results of the DNA-instability test are listed in Table 2. Comparison of various biomarkers in DNA-instability test positive adenoma and carcinoma is shown in Figure 3.

\section{DNA-instability test}

After hydrolysis with $2 \mathrm{~N} \mathrm{HCl}$ at $30^{\circ} \mathrm{C}$ for $20 \mathrm{~min}$, all cancer cells (Figure $1 \mathrm{~d}$ ) and all cells of severely dysplastic adenoma (Figure 1c) were positively stained without exception with anti-cytidine antibody, indicating increased DNA-instability in both lesions (positive DNA-instability test). On the other hand, normal epithelial cells, stromal fibroblasts, vascular endothelial cells and inflammatory cells in the same slide were negative. A quote of $20.7 \%$ (12/58) of mildly dysplastic adenoma were positive in the DNA-instability test, in which about $10 \%$ of dysplastic glands were positively stained (Figure

Table 2. Comparison of different biological markers in DNA-instability test-positive and -negative adenomas. The statistical differences of KI values were examined by Student's t-test. The statistical differences of p53. DFF45. and bFGF positivity were examined by the Chi-square test. Significant differences are indicated by asterisks.

\begin{tabular}{|c|c|c|c|c|c|c|}
\hline & DNA-instability test & $\%$ & $\begin{array}{c}K l \\
(\text { mean } \pm S . D .)\end{array}$ & $\begin{array}{l}p 53 \\
(\%)\end{array}$ & $\begin{array}{l}\text { DNA-fragmentation factor } \\
(\%)\end{array}$ & $\begin{array}{l}\text { bFGF } \\
(\%)\end{array}$ \\
\hline \multirow[t]{2}{*}{ Mild dysplasia ( $(n=58)$} & $\begin{array}{l}\text { positive } \\
(\mathrm{n}=12)\end{array}$ & 20.7 & $49.89 \pm 11.21 * *$ & $\begin{array}{l}83.3^{* *} \\
(10 / 12)\end{array}$ & $\begin{array}{l}100^{* *} \\
(12 / 12)\end{array}$ & $\begin{array}{l}75.0^{* *} \\
(9 / 12)\end{array}$ \\
\hline & $\begin{array}{l}\text { negative } \\
(n=46)\end{array}$ & 79.3 & $20.69 \pm 9.96$ & $\begin{array}{c}21.7 \\
(10 / 46)\end{array}$ & $\begin{array}{c}47.8 \\
(22 / 46)\end{array}$ & $\begin{array}{c}21.7 \\
(10 / 46)\end{array}$ \\
\hline \multirow[t]{2}{*}{ Moderate dysplasia $(\mathrm{n}=86)$} & $\begin{array}{l}\text { positive } \\
(\mathrm{n}=52)\end{array}$ & 60.5 & $68.25 \pm 10.11 * *$ & $\begin{array}{l}80.8^{* *} \\
(42 / 52)\end{array}$ & $\begin{array}{l}94.2 * * \\
(49 / 52)\end{array}$ & $\begin{array}{l}65.4^{* *} \\
(34 / 52)\end{array}$ \\
\hline & $\begin{array}{l}\text { negative } \\
(\mathrm{n}=34)\end{array}$ & 39.5 & $43.33 \pm 15.54$ & $\begin{array}{c}41.2 \\
(14 / 34)\end{array}$ & $\begin{array}{c}32.4 \\
(11 / 34)\end{array}$ & $\begin{array}{c}20.6 \\
(7 / 34)\end{array}$ \\
\hline Severe dysplasia ( $=20$ ) & $\begin{array}{l}\text { all-positive } \\
\quad(\mathrm{n}=20)\end{array}$ & 100 & $75.19 \pm 12.58$ & $\begin{array}{c}90.0 \\
(18 / 20)\end{array}$ & $\begin{array}{c}90.0 \\
(18 / 20)\end{array}$ & $\begin{array}{c}75.0 ? \\
(15 / 20)\end{array}$ \\
\hline \multirow[t]{2}{*}{ Total dysplasia $(\mathrm{n}=164)$} & $\begin{array}{l}\text { positive } \\
(\mathrm{n}=84)\end{array}$ & 51.2 & $67.78 \pm 18.74^{* *}$ & $\begin{array}{l}83.3^{* *} \\
(\mathrm{n}=70)\end{array}$ & $\begin{array}{l}94.1^{* *} \\
(\mathrm{n}=79)\end{array}$ & $\begin{array}{l}69.1 * * \\
(\mathrm{n}=58)\end{array}$ \\
\hline & $\begin{array}{l}\text { negative } \\
(\mathrm{n}=80)\end{array}$ & 48.8 & $36.45 \pm 10.45$ & $\begin{array}{c}30.0 \\
(n=24)\end{array}$ & $\begin{array}{c}41.3 \\
(n=33)\end{array}$ & $\begin{array}{c}21.3 \\
(\mathrm{n}=17)\end{array}$ \\
\hline
\end{tabular}




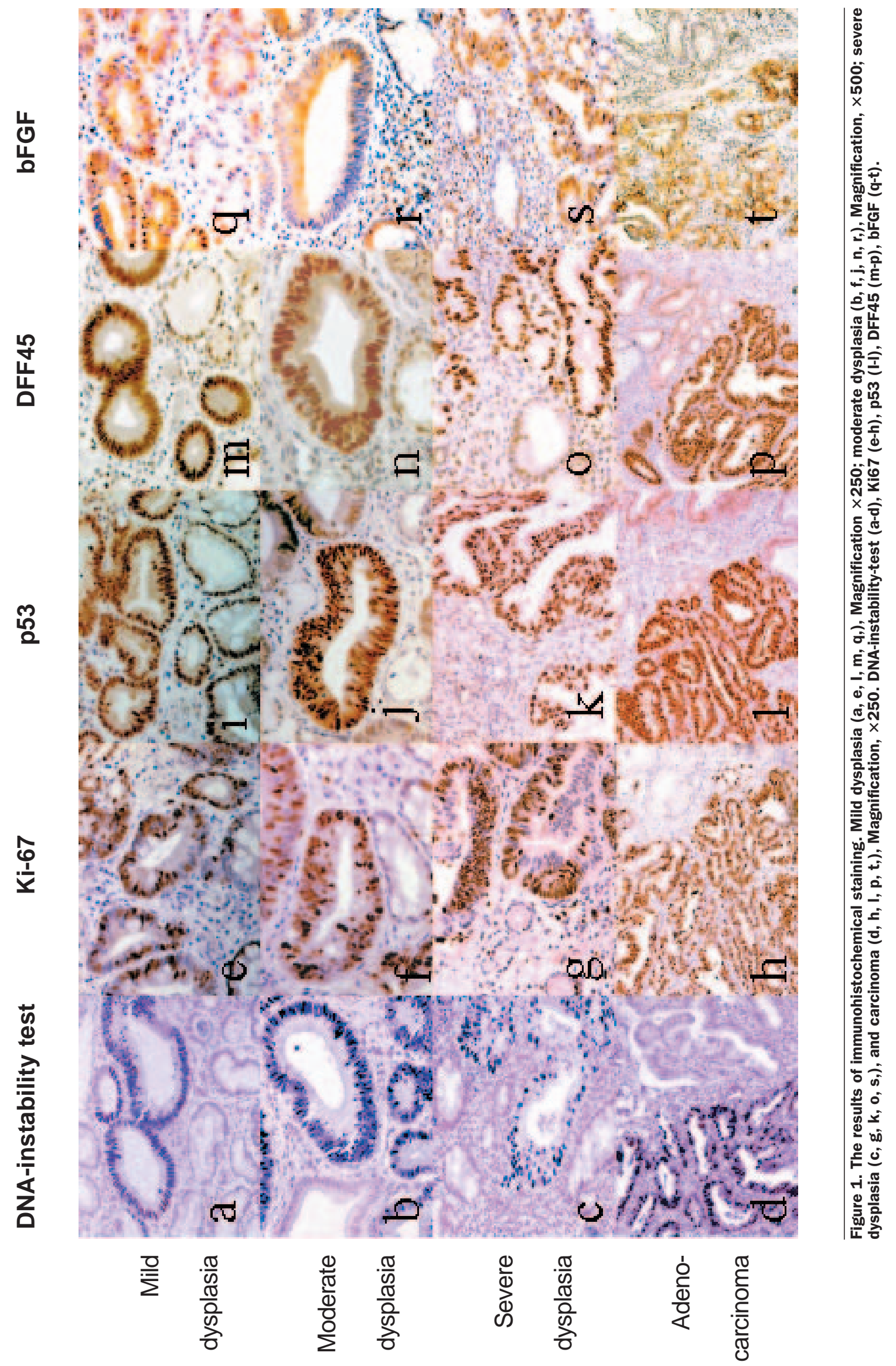




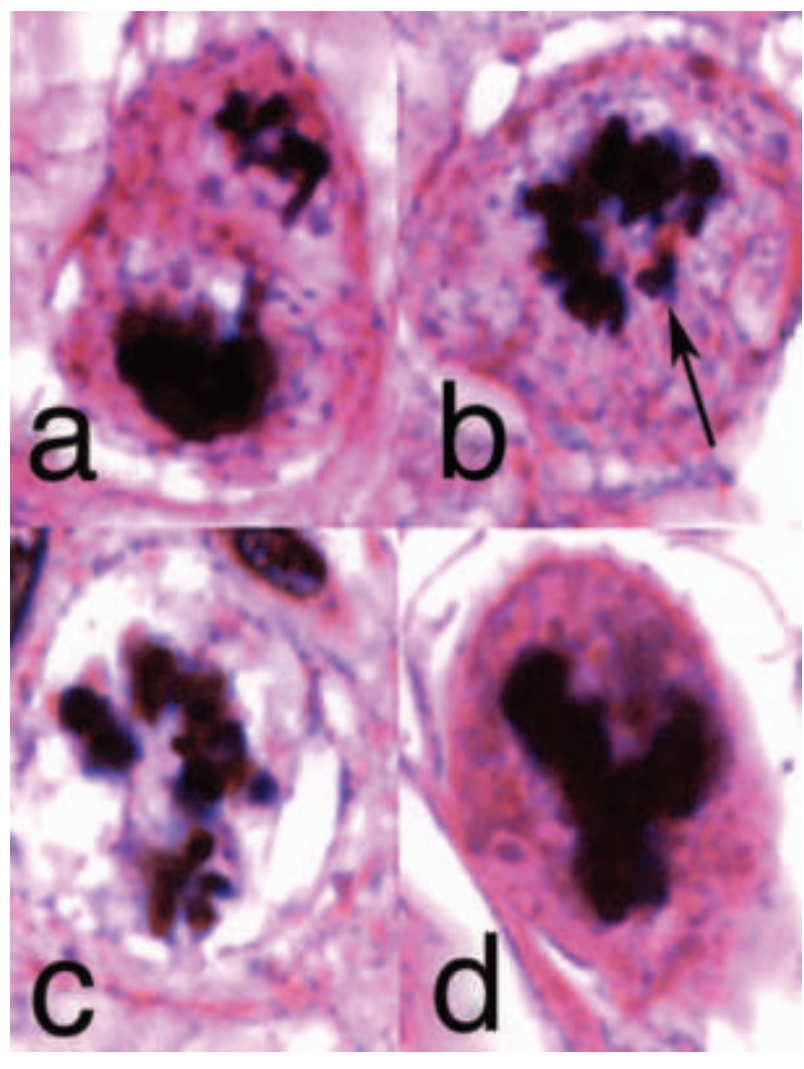

Figure 2. Abnormalities in mitosis figures seen exclusively in the DNA-instability test-positive glands in adenomas. Asymmetric mitosis (a), small chromosomal fragment separated (indicated by the arrow), (b), tripolar mitosis (c, d). Magnification $\times \mathbf{1 0 0 0}$.

1a). About $60.5 \%$ (52/86) of moderately dysplastic adenoma were positive in the DNA-instability test, in which about $40 \%$ of dysplastic glands were positively stained (Figure lb). These positivelystained glands showed increased DNA-instability comparable to that of cancer cells. In the remaining cases with negative DNA-instability, no positive gland $s$ were found. Thus, the extent of immunostaining with anti-cytidine antibody increased with histological grade (Table 1), which was statistically significant $(p<0.05)$. No apparent morphological differences were, however, identified between DNAinstability test-positive and -negative glands.

\section{Presence of abnormal mitosis in DNA-instability test-positive glands}

We also counted the percent numbers of normal mitosis and abnormal mitosis in the DNA-instability test-positive and -negative glands, respectively

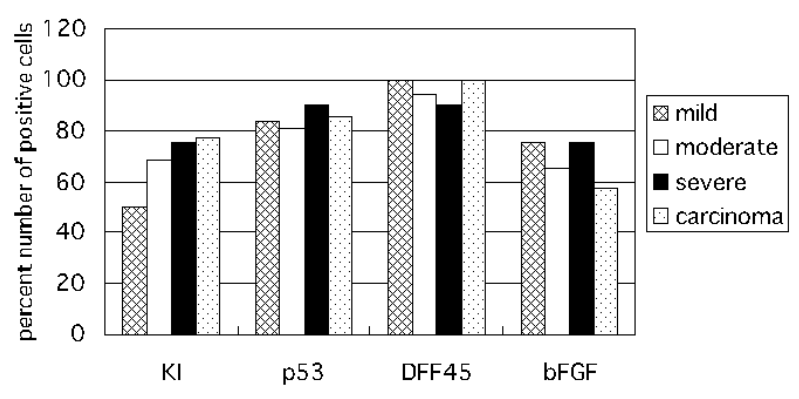

Figure 3. Comparison of various biomarkers in the DNA-instability test-positive glands of adenoma and carcinoma. The positive proportions of all biomakers in adenoma were comparable to those in carcinomas, irrespective of the dysplasia grade, without statistical significance.

(Figure 2). Abnormal mitosis was only observed in DNA-instability test-positive glands, and the average numbers were $0.3 \%, 0.5 \%, 1.9 \%$, and $2 \%$ in mild, moderate, severe adenoma and adenocarcinoma, respectively. Whereas the numbers of normal mitosis tended to be slightly larger in the DNAinstability test-positive glands, no statistical difference was found compared to that in DNA-instability test-negative glands. The average numbers were $0.5 \%, 1.1 \%, 4.1 \%$, and $3.9 \%$, in mild, moderate, and severe adenoma and adenocarcinoma, respectively.

\section{Ki67 immunohistochemistry}

Ki67 immunoreactivity was observed exclusively in the nuclei of cells (Figure le-h). In foveolar hyperplastic polyp and normal mucosal epithelium surrounding adenoma or carcinoma, Ki67-positive cells were observed only sporadically. In adenoma and carcinoma, Ki67 positively-stained cells were present diffusely, indicating the loss of polarity of proliferating cells. KI was significantly higher in adenocarcinoma, severe and moderate dysplasia than those in foveolar hyperplastic polyp and mild dysplasia (Table 1). Furthermore, KI of the DNAinstability test-positive cases was statistically higher than that of -negative cases $(p<0.01)$, both in mild and moderate dysplasia (Table 2). Moreover, KI of DNA-instability test-positive adenoma glands were comparable to that of adenocarcinomas, irrespective of adenoma grade (Figure 3 ). 


\section{P53 immunohistochemistry}

P53 immunoreactivity was limited to the nuclei of cells (Figure $1 \mathrm{i}-\mathrm{I}$ ). Foveolar hyperplastic polyp and normal mucosal epithelium surrounding adenoma or carcinoma were negative for p53. On the other hand, as shown in Table 1, the percentages of p53positive cases in mild, moderate, and severe dysplasia, whole dysplastic lesion and adenocarcinoma were 34.5, 65.1, 90, 57.3 and 85.7, respectively. There was a significantly higher p53 positivity in carcinoma, severe and moderate dysplasia than that in mild dysplasia $(p<0.05)$ (Table 1$)$. Furthermore, among the 12 mild and 52 moderate dysplasias with a positive DNA-instability test, $10(83.3 \%)$ and 42 $(80.8 \%)$ cases were also positive for p53, whereas among 46 mild and 34 moderate dysplasias with a negative DNA-instability test, only $10(21.7 \%)$ and $14(41.2 \%)$ cases expressed p53 positivity, respectively. The proportions of p53-positive cases with a positive DNA-instability test were statistically higher than those with a negative DNA-instability test $(p<0.01)$, both in mild and moderate dysplasia (Table 2). Moreover, in all dysplasia and adenocarcinoma lesions with a positive DNA-instability test, the distribution of p53-positive cells coincided well with those of DNA-instability test-positive cells, and the percent numbers of p53-positive cells in the DNA-instability test-positive adenoma glands were comparable to that of adenocarcinomas, irrespective of adenoma grade (Figure 3 ).

\section{DNA-fragmentation factor 45 immunohistochem- istry}

The proportions of DFF45-positive cases among foveolar hyperplastic polyp, mild, moderate and severe dysplasia, whole dysplastic lesions and adenocarcinoma were 7.7, 58.6, 69.8, 90, 68.3, and $100 \%$, respectively. The proportion of DFF45-positive cases in severe dysplasia and adenocarcinoma were significantly different from that in mild dysplasia, but were not different between moderate dysplasia and mild dysplasia (Table 1 ).

As shown in Table 2, the proportion of DFF45positive cases with a positive DNA-instability test were significantly higher than that with a negative DNA-instability test. The distribution of DFF45positive cells in all cases correlated well with that of DNA-instability test-positive cells (Figure $1 \mathrm{~m}-\mathrm{p}$ ).

\section{bFGF immunohistochemistry}

bFGF immunoreactivity was detected in cyto- plasm. The proportions of bFGF-positive cases among mild, moderate, and severe dysplasia, whole dysplastic lesion and adenocarcinoma were 32.8, $47.7,75,45.7$ and $57.1 \%$, respectively. Severe dysplasia had a significantly higher bFGF expression rate than that of mild and moderate dysplasia (Table 1 ). In addition, the distribution of bFGF-positive cells correlated well with that of DNA-instability test-positive cells (Figure 1q-t). Furthermore, the proportion of bFGF-positive cases with a positive DNA-instability test were significantly higher than that with a negative DNA-instability test, both in mild and moderate dysplasia (Table 2). In the DNA-instability test-positive adenomas, 75\% (9/12) of mildly dysplastic adenoma, $65.4 \%$ (34/52) of moderately dysplastic adenoma, and $75 \%(15 / 20)$ of severely dysplastic adenoma were positive for bFGF, and these values were comparable to those of adenocarcinoma, $57.1 \%$ (8/14) (Figure 3).

\section{Discussion}

As for the degree of malignant potential of gastric adenoma, a great number of controversial reports have been so far proposed. Some authors believe that the malignant transformation of gastric adenoma is rare (Carey and Hay, 1948; Hay, 1953; Plachta and Speer, 1957; Monaco et al., 1962) but others reported the high incidence of malignant transformation of gastric adenoma, regarding it as precancerous (Nakamura et al., 1966; Sugano et al., 1971; Tomasulo, 1971; Morson et al., 1980; Kamiya et al., 1982; Nakamura et al., 1988; Rugge et al., 1991; Farinati et al., 1993). Apparent cancer lesion has, in fact, been discovered in gastric adenoma (Sugano et al., 1971; Kamiya et al., 1982; Coma-del Corral et al., 1991).

The incidence of gastric carcinoma is reported to be very high in Japan in comparison with Western countries, and $30-50 \%$ of all gastric carcinomas in Japan are diagnosed as early gastric cancer without invasion beyond the submucosal layer (Kaneko et al., 1977; Hirota and Ming, 1992; Sano et al., 1992).

In Western countries, gastric adenoma is diagnosed when evident invasive growth of neoplastic epithelium into the lamina propria of the mucosa or beyond is observed (Lansdown et al., 1990; Lewin et al., 1992), but most Japanese pathologists, on the other hand, make diagnosis of carcinoma on the basis of nuclear and structural atypia irrespective of 
whether or not there is invasion into the lamina propria. This will partly explain the discrepancies in the reported frequencies of malignant transformation of gastric adenoma (Schlemper et al., 1997).

In order to detect the cancer clones in the very early stage of progression, certain breakthroughs are necessary.

Based on the finding that all cancerous cells produce much more single-stranded DNA than normal cells after acid hydrolysis, Fukuda et al. (1986, 1993) developed the method of staining cancerous cells specifically with acridine orange or anti-cytidine antibody after acid hydrolysis and called it as the DNA-instability test as a specific marker for malignancy irrespective of epithelial or mesenchymal origin. Since the first report (Fukuda et al., 1986), more than 20,000 malignancy cases and socalled borderline malignancy cases were tested by this method ( Nitta et al., 1993; Otaki et al., 1994; Tsuzuki et al., 1994; Azuchi et al., 1998; Khaled et al., 2000; Hirai et al., 2001; Ishida et al., 2001; Iwasa et al., 2001), and all cancerous cells were found to be positively stained in the DNA-instability test, while comparable normal cells, vascular endothelial cells, fibroblasts and inflammatory cells present in the same slides were completely negative.

In these studies, and also in the present study, the DNA-instability-positive lesions showed significantly higher values of positivity of other biomarkers. Furthermore, many abnormal mitoses were found predominantly in the DNA-instability test-positive lesions as shown in the present study (Figure 2 ) and other reports (Tsuzuki et al., 1994; Azuchi et al., 1998); and the frequency of chromosome 17 polysomies and the percentage of hyperdiploid cells measured by means of the chromosome index using interphase cytogenetics increased significantly and exclusively in the DNA-instability test-positive lesions (Khaled et al., 2000; Ishida et al., 2001). This is also supported by the report that numerical chromosomal aberration is associated with cancer progression (Bulten et al., 1998). These findings clearly showed the existence of DNA or chromosomal abnormalities in these DNA-instability test-positive lesions, indicating their malignant character, although no drastic progression showing marked morphological atypia is taking place.

The mechanism of increased DNA-instability against acid hydrolysis in malignancy is not fully understood, but possible mechanisms have been proposed (Hatchoh et al., 1992; Fukuda et al., 1993;
Nitta et al., 1993; Otaki et al., 1994). Nuclear pleomorphism with altered chromatin structures and contents, used as the most reliable morphological criteria for daily pathological diagnosis of malignancy, will be a direct reflection of a changed chemical nature and spatial configuration of nuclear DNA. Various carcinogens will induce genomic damage with single and double DNA-strand breaks, and erroneous repair and successive cell proliferation with DNA synthesis will exaggerate the damage, resulting in increased DNA-instability. In order to accomplish the effective and complete packing of nuclear DNA, cells will need sufficient amounts of histones to form nucleosomes in proportion to the amount of nuclear DNA. Disturbed functions of histone production by certain gene damages will disturb the DNA packing function and it may result in abnormal chromatin configuration that will also induce increased DNA-instability upon acid hydrolysis.

Another possible mechanism of increased DNAinstability of malignancy may be attributable to the production of active oxygen by cancerous cells (Noriki et al., 1989; Fukuda et al., 1993). In the cell membrane of cancerous cells, the amount of unsaturated fatty acids is known to be increased (Wood et al., 1985) with increased lipid peroxide (Noriki et al., 1989; Otamiri and Sjodhal, 1989), because unsaturated fatty acids are susceptible to peroxidation to produce lipid peroxide. The latter is included in the group of active oxygen, and may be the source of radical chain reactions producing further active oxygen. Active oxygen modifies enzymatic and structural proteins, rendering them susceptible to proteolytic attack (Levine et al., 1981; Dean, 1987), and gives rise to membrane damage through lipid peroxidation. This harmful chain reaction induces the inactivation of the enzymes needed as scavengers. These finally induce serious DNA damage by modification, strand-break, and oxidative degeneration (Van Hemmen and Meuling, 1975; Peskin and Shlyanova, 1986; Kasai and Nishimura, 1986; Noriki et al., 1989).

Recently, a very large number of reports concerning DNA-instability have been presented using methods for detecting chromosomal fragile sites (Ohta et al., 1996; Pennisi E, 1996), loss of heterozygosity (White et al., 1985; Yokota et al., 1989a; Yokota et al., 1989b; Kallioniemi A., 1992), and microsatellite instability (Hearne et al., 1992; Jego et al., 1993; Thibodeau et al., 1993; Thompson 
et al., 1992). It was shown that the microsatellite instability was particularly closely related to the progression of gastric adenoma to adenocarcinoma, reflecting the abnormalities of the DNA mismatch repair system (Semba et al., 1996; Kim et al., 1999; Kashiwagi et al., 2000). These methods, however, only demonstrated the presence of qualitative or quantitative changes in certain specific genomic loci. In contrast to these commonly used methods to reveal the DNA-instability at certain specific DNA regions, the DNA-instability test used in the present study revealed the presence of physical DNA-instability in the entire DNA molecule as revealed by increased liability to denature upon $\mathrm{HCl}$ hydrolysis.

The DNA-instability test used in the present study was also previously applied to the analysis of chemical carcinogenesis of mouse skin cancer by 20 methylcholanthrene and succeeded in detecting cancer clones in the very early stage of its progression only 2 weeks after starting the topical applications (Hirai et al., 2001). These cancer clones demonstrated enhanced proliferative activity as revealed by PCNA (Bravo et al., 1987; Wong et al., 1987) immunohistochemistry, mutation of p53 (a gene producing a protein which inhibits the entrance of abnormal cells through the G1-S checkpoint and push these to apoptosis even after slipping into the $S$ phase) (Finlay et al., 1988; Hollstein et al., 1991), induction of DFF45 (an inhibitory protein which inhibits DNA-fragmentation at the final step of apoptosis) (Liu et al., 1997; Enari et al., 1998; Sabol et al., 1998; Sasaki et al., 1999) and paracrine secretion of VEGF (vascular endothelial growth factor, a protein which induces vascular endothelial cell proliferation) (Leung et al., 1989) with the induction of neovascularization. All these changes should favor an increase in the number of descendants of the cancer clones to accept abundant nutrients, and have a higher chance to survive by escaping the apoptotic machinery (Hirai et al., 2001; Iwasa et al., 2001).

Similar results were obtained in the present study. The proliferative activation, this time, expressed as KI (Schlüter et al., 1993), p53 mutation, induction of the DFF45, and bFGF (a protein which has a similar effect as VEGF) (Folkman and Klagsbrum, 1987; Russell, 1989), were all predominantly seen in the DNA-instability test-positive glands (Table 2).

But the degrees of positivity of these biomarkers were statistically not different in the DNA-instabil- ity test-positive glands in all mild, moderate, and severe dysplasia of adenoma and cancer (Figure 3 ). Judging from these results, the DNA-instability testpositive glands in mildly dysplastic adenoma should be already regarded as cancer clones at the early stage of progression. $20.7 \%$ of mildly dysplastic adenoma were positive in the DNA-instability test in which only $10 \%$ of dysplastic glands were positively stained. Therefore, a large number of glands involved in mildly dysplastic adenoma should be reactive in nature showing simple hyperplasia, although small cancer buds co-exist in some of them.

We previously proposed the concept of procancer (not pre-cancer) to designate the cancer clones as a stage in the course of carcinogenesis and cancer progression (Hirai et al., 2001; Iwasa et al., 2001). Procancer lesions represent the cancer clones at a very early stage of malignancy without distinguishable morphological atypia but with a positive DNAinstability test and other biomarkers such as PCNA, Ki67, p53, VEGF, bFGF, and DFF45. We also defined the abnormal positivities of these biomarkers including the DNA-instability test as functional atypia, compared with the commonly used morphological atypia.

While morphological criteria and existence of invasion seem to be the most reliable markers for the diagnosis of malignancy, it appears that a certain period is required before the degree of morphological atypia is manifested histopathologically to allow the diagnosis of malignancy, even after the formation of cancer clones. During the extremely long, incipient (1-4 years) and early (14-21 years) phases of tumor growth of gastric cancer (Fujita, 1978), the DNA alterations induced in cancer cells, which should be minute initially, will become intensified and exaggerated by repeated cell divisions (Hatchoh et al., 1992) during these long phases so as to make the diagnosis of cancer by pathologists possible based on the degree of morphological atypia. Further progression of cancer clones will produce the subclones with the potency to invade.

The cancer clones present in the adenoma lesions could be regarded as procancer clones. Reflecting the malignant character of the procancer clones in adenomas, abnormal mitoses are exclusively encountered in the DNA-instability test-positive glands, reflecting the chromosomal abnormalities evoked by DNA- or genomic instability (Steinbeck, 2001). 
Thus, all gastric adenoma lesions should be completely removed by EMR or polypectomy irrespective of the histological grades, although their progression to full blown carcinomas with sufficient morphological atypia and invasive potency may need more than several years.

\section{References}

Ayhan A, Yasui W, Yokozaki H, Seto M, Ueda R, Tahara E. Loss of heterozygosity at the bcl-2 gene locus and expression of bcl-2 in human gastric and colorectal carcinomas. Jpn J Cancer Res 1994;85:58491.

Azuchi M, Baba H, Imura S, Noriki S, Imamura $Y$, Fukuda M. Demonstration of biological aggressiveness of bone giant cell tumor by the comparative study of immunohistochemical detection of DNAinstability and cortical bone destruction by CT. Acta Histochem Cytochem 1998;31:401-10.

Bearzi I, Ranaldi R, Santinelli A, Mannello B, Mariuzzi GM. Epithelial dysplasia of the gastric mucosa. A morphometric and ploidy pattern study. Pathol Res Pract 1992;188:550-5.

Bravo R, Frank R, Blundell PA, Macdonald-Bravo H. Cyclin/PCNA is the auxiliary protein of DNA polymerase delta. Nature 1987;326: 515-7.

Bulten J, Poddighe PJ, Robben JC, Gemmink JH, de Wilde PC, Hanselaar AG. Interphase cytogenetic analysis of cervical intraepithelial neoplasia. Am J Pathol 1998;152:495-503.

Carey JB, Hay LJ. Gastric polyps. Gastroenterol 1948;10:102-7.

Coma-del-Corral MJ, Carretero-Albinana L, Ojeda-Gimenez C. Depressed adenoma of the stomach. Conceptual review and study of five cases. J Clin Gastroenterol 1991;13:353-7.

Correa P. Human gastric carcinogenesis: a multistep and multifactorial process-First American Cancer Society award lecture on cancer epidemiology and prevention. Cancer Res 1992;52:6735-40.

Dean RT. A mechanism for accelerated degradation of intracellular proteins after limited damage by free radicals. FEBS Lett 1987;220: 278-82.

D’Errico A, Garbisa S, Liotta LA, Castronovo V, Stetler-Stevenson WG, Grigioni WF. Augmentation of type IV collagenase, laminin receptor and Ki67 proliferation antigen associated with human colon, gastric and breast carcinoma progression. Mod Pathol 1991;4:239-46.

Di Gregorio C, Morandi P, Fante R, De Gaetani C. Gastric dysplasia: a follow-up study. Am J Gastroenterol 1993;88:1714-9.

Enari M, Sakahira H, Yokoyama H, Okawa K, Iwamatsu A, Nagata S. A caspase-activated DNase that degrades DNA during apoptosis, and its inhibitor ICAD. Nature 1998;391:43-50.

Farinati $F$, Cardin F, Di Mario F, Valiante F, Naccarato R, ArslanPagnini $C$, et al. Follow-up in gastric dysplasia patients. Am. J. Surg. Pathol 1989;13:173-4.

Farinati F, Rugge M, Valiante F, Baffa R, Di Mario F, Naccarato R. Gastric epithelial dysplasia. Gut 1991;32:457.

Farinati F, Rugge M, Di Mario F, Variante F, Baffa R. Early and advanced gastric cancer in the follow-up of moderate and severe gastric dysplasia patients. A prospective study. I.G.G.E.D. Interdisciplinary Group on Gastric Epithelial Dysplasia. Endoscopy 1993; 25:261-4.

Fenoglio-Preiser C, Carneiro F, Correa P, Guilford P, Lambert R, Megraud $F$, et al. Gastric carcinoma. In World Health Organization Classification of Tumours Pathology and Genetics of Tumours of the Digestive System. Hamilton SR and Aaltonen LA, Eds. IARC Press: Lyon; 2000. p. 37-68.

Fertitta AM, Comin U, Terruzzi V, Minori G, Zambelli A, Cannatelli G, et al. Clinical significance of gastric dysplasia: a multicenter followup study. Gastrointestinal Endoscopic Pathology Study group. Endoscopy 1993;25:265-8.

Finlay CA, Hinds PW, Tan TH, Eliyahu D, Oren M, Levine AJ. Activating mutations for transformation by $\mathrm{p} 53$ produce a gene product that forms an hac 70-p53 complex with an altered half-life. Mol Cell Biol 1988;8:531-9.

Folkman J, Klagsbru M. Angiogenic factors. Science 1987;235:442-7. Fujita S. Biology of early gastric carcinoma. Pathol Res Pract 1978; 163:297-309.

Fukuda M, Miyoshi N, Hattori T, Sugihara H, Hosokawa Y, Nakanishi K. Different instability of nulear DNA at acid hydrolysis in cancerous and noncancerous cells as revealed by fluorescent staining with acridine orange. Histochemistry 1986;84:556-60.

Fukuda M, Noriki S, Imamura Y, Miyoshi N, Kimura S, Koizumi K, et al. Differential immunohistochemical staining of cancerous cells with anti-single-stranded DNA antiserum in ordinary pathological paraffin section after DNA-denaturation by acid hydrolysis. Eur J Histochem 1993;37:309-19.

Goldstein NS, Lewin KJ. Gastric epithelial dysplasia and adenoma: Historical review and histological criteria for grading. Hum Pathol 1997;28:127-33.

Hatchoh M, Ueda K, Imamura Y, Noriki S, Fukuda M. Qualitative and quantitative changes in nuclear DNA and phenotypic gene expression in human malignant skin tumors during their progression. Eur $\mathrm{J}$ Histochem 1992;36:289-302.

Hay LJ. Polyps and adenomas of the stomach. Surgery 1953;33:44667.

Hearne CM, Ghosh S, Todd JA. Microsatellites for linkage analysis of genetic traits. Trends Genet 1992;8:288-94.

Hirai K, Kumakiri M, Ueda K, Imamura $Y$, Noriki S, Nishi $Y$, et al. Clonal evolution and progression of 20-methylcholanthrene-induced squamous cell carcinoma of mouse epidermis as revealed by DNA instability and other malignancy markers. Eur J Histochem 2001; 45:319-32.

Hirota T, Ming SC. Early gastric carcinoma. In: Ming SC, Goldman H, Eds. Pathology of the gastrointestinal tract. Philadelphia: Saunders; 1992. p. 570-83.

Hollstein M, Sidransky D, Vogelstein B, Haris CC. p53 mutations in human cancers. Science 1991;253:49-53.

Hoshi T, Sasano H, Kato K, Yabuki N, Ohara S, Konno R, et al. Immunohistochemistry of Caspase3/CPP32 in human stomach and its correlation with cell proliferation and apoptosis. Anticancer Res 1998; 18:4347-53.

Ishida H, kumakiri M, Ueda K, Lao LM, Yanagihara M, Asamoto K, et al. Comparative histochemical study of Bowen's disease and actinic keratosis: preserved normal basal cells in Bowen's disease. Eur J Histochem 2001;45:177-90.

Iwasa M, Imamura $Y$, Noriki S, Nishi $Y$, Kato H, Fukuda M. Immunohistochemical detection of early-stage carcinogenesis of oral leukoplakia by increased DNA-instability and various malignancy markers. Eur J Histochem 2001;45:333-46.

Jass JR, Filipe MI. Sulphomucins and precancerous lesions of the human stomach. Histopathology 1980;4:271-9.

Jego N, Thomas G, Hamelin R. Short direct repeats flanking deletions and duplicating insertions in $\mathrm{p} 53$ gene in human cancers. Oncogene 1993;8:209-13.

Kallioniemi A, Kallioniemi OP, Sudar D, Rutovitz D, Gray JW, Waldman $\mathrm{F}$, et al. Comparative genomic hybridization for molecular cytogenetic analysis of solid tumors. Science 1992;258:818-21.

Kamiya T, Morishita T, Asakura H, Miura S, Munakata Y, Tsuchiya M. Long-term follow-up study on gastric adenoma and its relation to gastric protruded carcinoma. Cancer 1982;50:2496-503.

Kaneko E, Nakamura T, Umeda N, Fujino M, Niwa H. Outcome of gastric carcinoma detected by gastric mass survey in Japan. Gut 1977; 18:626-30.

Kasai $\mathrm{H}$, Nishimura $\mathrm{S}$. Hydroxylation of guanine in nucleosides and DNA at the $\mathrm{C}-8$ position by heated glucose and oxygen radical-forming agents. Environ Health Perspect 1986;67:111-6.

Kashiwagi K, Watanabe M, Ezaki T, Kanai T, Ishii H, Mukai M, et al. Clinical usefulness of microsatellite instability for the prediction of gastric adenoma or adenocarcinoma in patients with chronic gastritis. Br J Cancer 2000;82:1814-8.

Khaled A, Imamura Y, Noriki S, Fukuda M. Early progression stage of malignancy of uterine cervical dysplasia as revealed by immunohistochemical demonstration of increased DNA instability. Eur J Histochem 2000;44:143-56.

Kim JJ, Baek MJ, Kim L, Kim NG, Lee YC, Song SY, et al. Accumulated 
frameshift mutations at coding nucleotide repeats during the progression of gastric carcinoma with microsatellite instability. Lab Invest 1999;79:1113-20.

Kim HS, Woo DK, Bae SI, Kim YI, Kim WH. Microsatellite instability in the adenoma-carcinoma sequence of the stomach. Lab Invest 2000;80:57-64.

Lansdown M, Quirke P, Dixon MF, Axon AT, Johnston D. High grade dysplasia of the gastric mucosa: a marker for gastric carcinoma. Gut 1990;31:977-83.

Leung DW, Cachianes G, Kuang WJ, Goeddel DV, Ferrara N. Vascular endothelial growth factor is a secreted angiogenic mitogen. Science 1989;246:1306-9.

Levine RL, Oliver CN, Fulks RM, Stadtman ER. Turnover of bacterial glutamine synthetase: Oxidative inactivation precedes proteolysis. Proc Natl Acad Sci USA 1981 78:2120-4.

Lewin KJ, Riddell RH, Weinstein WM. Gastrointestinal pathology and its clinical implications. New York: Igaku-shoin. 1992.

Liu $X$, Zou H, Slaughter $C$, Wang X. DFF, a heterodimeric protein that functions downstream of caspase-3 to trigger DNA fragmentation during apoptosis. Cell 1997;89:175-84.

Matozaki T, Sakamoto C, Suzuki T, Matsuda K, Uchida T, Nakano 0, et al. P53 gene mutations in human gastric cancer: wild-type 053 but not mutant p53 suppresses growth of human gastric cancer cells. Cancer Res 1992;52:4335-41.

Ming SC, Bajtai A, Correa P, Elster K, Jarvi OH, Munoz N, et al. Gastric dysplasia: significance and pathologic criteria. Cancer 1984;54: 1794-801.

Miracco C, Spina D, Vindigni C, Filipe MI, Tosi P. Cell proliferation patterns and p53 expression in gastric dysplasia. Int J Cancer 1995;62: 149-54.

Monaco AP, Castleman B, Roth SI, Welch CE. Adenomatous polyps of the stomach: a clinical and pathological study of 153 cases. Cancer 1962;15:465-7.

Morson BC, Sobin LH, Grundmann E, Johansen A, Nagayo T, SerckHanssen A. Precancerous conditions and epithelial dysplasia in the stomach. J Clin Pathol 1980;33:711-21.

Nakamura K, Sugano H, Takagi K, Fuchigami A. Histopathological study on early carcinoma of the stomach: Criteria for diagnosis of atypical epithelium. Gann 1966;57:613-20.

Nakamura K, Sakaguchi H, Enjoji M. Depressed adenoma of the stomach. Cancer 1988;62:2197-202.

Nakatsuru S, Yanagisawa A, Furukawa Y, Ichii S, Kato Y, Nakamura Y, et al. Somatic mutations of the APC gene in precancerous lesion of the stomach. Hum Mol Genet 1993;2:1463-5.

Nitta Y, Suzuki K, Kohli Y, Fujiki N, Imamura Y, Noriki S, et al. Early progression stage of malignancy of human colon border-line adenoma as revealed by immunohistochemical demonstration of increased DNA-instability. Eur J Histochem 1993;37:207-18.

Noriki S, Imamura Y, Ikeda T, Nakanishi K, Miyoshi N, Kohno M, et al. Multi-organ damage (MOD) induced by cancer cachexia and its pathogenesis. Basic Appl Histochem 1989:33:337-46.

Ohta M, Inoue $\mathrm{H}$, Cotticelli MG, Kastury K, Baffa R, Palazzo J, et al. The FHIT gene, spanning the chromosome $3 p 14.2$ fragile site and renal carcinoma-associated $t(3 ; 8)$ breakpoint, is abnormal in digestive tract cancers. Cell 1996;84:587-97.

Otaki T, Kohli Y, Fujiki N, Imamura Y, Fukuda M. Early progression stage of malignancy as revealed by immunohistochemical demonstration of DNA instability; I, human gastric adenomas. Eur J Histochem 1994;38:281-90.

Otamiri T, Sjodahl R. Increased lipid peroxidation in malignant tissues of patients with colorectal cancer. Cancer 1989;64:422-5.

Ozercan IH, Bahcecioglu IH, Ozercan MR, Bozlak N, Dogan C, Yekeler $H$. Proliferating cell nuclear antigen and nuclear organizer region for differential diagnosis of dysplasia and adenocarcinoma in gastric biopsies. Indian J Gastroenterol 2000;19:57-60.

Pennisi E. New gene forges link between fragile site and many cancers. Science 1996;272:649.

Peskin AV, Shlyahova L. Cell nuclei generate DNA-nicking superoxide radicals. FEBS Lett 1986;194:317-21.

Plachta A, Speer FD. Gastric polyps and their relationship to carcinoma of the stomach. Am J Gastroenterol 1957;28:160-75.

Rubio CA, Kato Y. DNA profiles in mitotic cells from gastric adenomas. Am J Pathol 1988;130:485-8.
Rugge M, Farinati F, Di Mario F, Baffa R, Valiante F, Cardin F. Gastric epithelial dysplasia: A prospective multicenter follow-up study from the interdisciplinary group on gastric epithelial dysplasia. Hum Pathol 1991;22:1002-8.

Rugge M, Farinati F, Baffa R, Sonego F, Di Mario F, Leandro G, et al. Gastric epithelial dysplasia in the natural history of gastric cancer: A multicenter prospective follow-up study. Interdisciplinary Group on Gastric Epithelial Dysplasia. Gastroenterol 1994;107:1288-96.

Russell R. Successful growth of tumours. Nature 1989;339:16-7.

Sabol SL, Li R, Lee TY, Abdul-Khalek R. Inhibition of apoptosis-associated DNA fragmentation activity in nonapoptotic cells: the role of DNA fragmentation factor-45 (DFF45/ICAD). Biochem Biophys Res Commun 1998;253:151-8.

Sano T, Kobori 0, Muto T. Lymph node metastasis from early gastric cancer: endoscopic resection of tumour. Br J Surg 1992;79:241-4.

Sanz-Ortega J, Sanz-Esponera J, Caldes T, Gomez de la Concha E, Sobel ME, Merino MJ. LOH at the APC/MCC gene (5Q21) in gastric cancer and preneoplastic lesions. Prognostic implications. Pathol Res Pract 1996;192:1206-10.

Saraga EP, Gardiol D, Costa J. Gastric dysplasia: a histological followup study. Am J Surg Pathol 1987;11:788-96.

Sasaki H, Suzuki T, Funaki N, Hoshi T, Iwabuchi M, Ohi R, et al. Immunohistochemistry of DNA fragmentation factor in human stomach and colon: its correlation to apoptosis. Anticancer Res 1999;19: 5277-82.

Sasano H, Date F, Imatani A, Asaki S, Nagura H. Double immunostaining for c-erbB-2 and p53 in human stomach cancer cells. Hum Pathol 1993;24:584-9.

Schlemper RJ, Itabashi M, Kato Y, Lewin KJ, Riddell RH, Shimoda T, et al. Differences in diagnostic criteria for gastric carcinoma between Japanese and Western pathologists. Lancet 1997;349:1725-9.

Schlüter C, Duchrow M, Wohlenberg C, Becker MH, Key G, Flad HD, et al. The cell proliferation-associated antigen of antibody Ki-67: A very large, ubiquitous nuclear protein with numerous repeated elements, representing a new kind of cell cycle-maintaining proteins. J Cell Bio 1993;123:513-22.

Semba S, Yokozaki H, Yamamoto S, Yasui W, Tahara E. Microsatellite instability in precancerous lesions and adenocarcinomas of the stomach. Cancer 1996;77:1620-7.

Shiao YH, Rugge M, Correa P, Lehmann HP, Scheer WD. p53 alteration in gastric precancerous lesions. Am J Pathol 1994;144:511-7.

Shimada S, Tashima S, Yamaguchi K, Matsuzaki H, Ogawa M. Carcinogenesis of intestinal-type gastric cancer and colorectal cancer is commonly accompanied by expression of brain (fetal)-type glycogen phosphorylase. J Exp Clin Cancer Res 1999;18:111-8.

Steinbeck RG. Pathologic mitoses and pathology of mitosis in tumorigenesis. Eur J Histochem 2001;45:311-8.

Sugano $\mathrm{H}$, Nakamura K, Takagi K. An atypical epithelium of the stomach. A clinico-pathological entity. Gann Monogr Cancer Res 1971; 11:257-69.

Thibodeau SN, Bren G, Schaid D. Microsatellite instability in cancer of the proximal colon. Science 1993;260:816-9.

Thompson AD, Shen $Y$, Holman K, Sutherland GR, Callen DF, Richards RI. Isolation and characterization of $(A C) n$ microsatellite genetic markers from human chromosome 16. Genomics 1992;13:402-8.

Tomasulo J. Gastric polyps. Histologic types and their relationship to gastric carcinoma. Cancer 1971;27:1346-55.

Tosi P, Baak JP, Luzi P, Miracco C, Lio R, Barbini P. Morphometric distinction of low- and high-grade dysplasias in gastric biopsies. Hum Pathol 1989;20:839-44.

Tsujitani S, Furusawa M, Hayashi I. Morphological factors aid in therapeutic decisions concerning gastric adenomas. Hepatogastroenterol 1992;39:56-8.

Tsuzuki H, Saito H, Imamura Y, Noriki S, Fukuda M. Early progression stage of malignancy as revealed by immunohistochemical demonstration of DNA instability; II otorhinolaryngeal borderline neoplastic lesions. Eur J Histochem 1994;38:291-302.

Van Hemmen JJ, Meuling WJ. Inactivation of biologically active DNA by $\gamma$-ray-induced superoxide radicals and their dismutation products singlet molecular oxygen and hydrogen peroxide. Biochem Biophys Acta 1975;402:133-41.

Wang J, Chi DS, Karin GB, Sosinski C, Miller LE, Burja I, Thomas E. Helicobacter pylori infection and oncogene expressions in gastric 


\section{A. Sun et al.}

carcinoma and its precursor lesions. Dig Dis Sci 2002;47:107-13.

White R, Leppert M, Bishop DT, Barker D, Berkowitz J, Brown C, et al. Construction of linkage maps with DNA markers for human chromosomes. Nature 1985;313:101-5.

Wong RL, Katz ME, Ogata K, Tan EM, Cohen S. Inhibition of nuclear DNA synthesis by an autoantibody to proliferating cell nuclear antigen/cyclin. Cell Immunol 1987;110:443-8.

Wood CB, Haibib NA, Apostolov K, Thompson A, Barker W, Hershman $M$, et al. Reduction in the stearic to oleic acid ratio in human malignant liver neoplasms. Eur J Surg Oncol 1988;11:347-8.

Wu MS, Shun CT, Wang HP, Sheu JC, Lee WJ, Wang TH, et al. Genetic alterations in gastric cancer: relation to histogical subtypes, tumor stage, and helicobacter pylori infection. Gastroenterol 1997;112:
$1457-65$

Xuan ZX, Ambe K, Enjoji M. Depressed adenoma of the stomach, revisited histologic, histochemical, and immunohistochemical profiles. Cancer 1991;67:2382-9.

Yabuki N, Sasano H, Kato K, Ohara S, Toyota T, Nagura H, et al. Immunohistochemical study of DNA topoisomerase II in human gastric disorders. Am J Pathol 1996;149:997-1007.

Yokota J, Mori N, Akiyama T, Shimosato Y, Sugimura T, Terada M. Multiple genetic alterations in small-cell lung carcinoma. Princess Takamatsu Symp 1989;20:43-48[abstract].

Yokota J, Tsukada Y, Nakajima T, Gotoh M, Shimosato Y, Mori N, et al. Loss of heterozygosity on the short arm of chromosome 3 in carcinoma of the uterine cervix. Cancer Res 1989b;49:3598-601. 